\title{
VIABILITY OF COMPUTER-BASED EXAMINATION IN DEVELOPING NATIONS: THE WAY FORWARD
}

\author{
Alimi O. Maruf ${ }^{1}$, Amidu A. Quazeem ${ }^{2}$, K. Jimoh ${ }^{3}$ and F.O. Alimi ${ }^{4}$ \\ ${ }^{1}$ Computer Science Unit, Department of Physical Sciences, \\ Al-Hikmah University, Ilorin, Nigeria \\ ${ }^{2}$ Shehu Shagari College of Education, Sokoto-Nigeria \\ ${ }^{3}$ Statistics Unit, Department of Physical Sciences \\ Al-Hikmah University, Ilorin, Nigeria \\ ${ }^{4}$ Sultan Bello Secondary School, Sokoto-Nigeria
}

\begin{abstract}
Computer-based examination is becoming order of the day in almost all developed, developing and under developed nations. This is due to its advantages over paper means of testing. Unfortunately, some of the developing countries are adopting it without thorough examination of its feasibility, practicability, capability and possibility. This study tried to educate the public, government and examination bodies on the issues on ground that needs special attention before its full implementation. Data were gathered, analyzed and interpreted to show clear picture of present situation and the way forward.
\end{abstract}

\section{KEYWORDS}

(Computer, E-exam, Capability, Viability and Possibility)

\section{INTRODUCTION}

E-examination and any computer-based examinations become imperative for reliable, dependable, trustworthy and successful means of examining student in an institution, candidates seeking for job, admission and so on. But student at secondary level in most of developing countries such as Nigeria needs special attention for the present level of computer teachers in schools, number of computer in their laboratories, and their exposures to computer practical [1].

Education is a productive system with sets of inputs in the form of human and material resources and undergoes certain process aimed at producing specific output. The outputs are expected to satisfy determined objective of the organizational systems. Computer is deeply involved in various aspect of our lives today than any other technology ever known to man[2]. Therefore, if computer should be one of the materials for production of qualitative examination results and as one of the material resources for education, many things are needed to be looked into. 
Secondary education is one of the most important level in educational system from view point of an education planner, secondary educational system with its consumer and producer status, secondary education do not only determine the fact but also dictates the pace of education at primary and tertiary level of education throughout the world[3].

The best innovation in the secondary education system these days is the introduction of computer education. Computer as an electronic device that receives data and instruction as input, stores, manipulate and yields information at a tremendous speed. It has today been identified as an indispensable tool of development in almost all aspect of human endeavour and the use of computers and network technology in classrooms has become increasingly common place as well.

The examination bodies such as Joint Admission and Matriculation Body (JAMB) and West African Examination Council (WAEC) that are now trying to use computer have taught well and good for the benefit of all and sundry in Nigeria but it could have been better if some things are put into consideration for it successful implementation.

\section{OBJECTIVES}

Ultimately, the main aim of this study is to examine the preparedness of the stakeholders for the take off of e-examination by our examination bodies. The specific objectives are to check how are schools ready for the introduction of E-JAMB and E-WAEC; examine the number of systems available in schools, volume of students in schools in relation to the systems, availability of qualified teachers, availability of related materials such as electricity, network, internet services in the schools and to see if there is hope for better future. The outcome of this research will facilitate educational development, computer education and successful computer -based examination in general.

\section{METHODOLOGY}

This study essentially confined itself to some selected secondary schools in Sokoto State metropolis in Nigeria. Questionnaire, Interview and observation methods were used with analysis of data and graphical data presentation.

\section{DATA ANALYSIS AND FINDINGS}

This section presents data analysis and findings obtained from various respondents of the selected secondary schools. 
International Journal of Computer Science, Engineering and Applications (IJCSEA) Vol.6, No.1, February 2016

Table 1: Analysis of Student Responses

\begin{tabular}{|c|l|c|c|c|c|}
\hline S/N & \multicolumn{1}{|c|}{ ITEM } & YES & \% & NO & \% \\
\hline I & $\begin{array}{l}\text { Are you allowed to use computer by } \\
\text { your computer teacher? }\end{array}$ & 9 & 15 & 51 & 85 \\
\hline Ii & $\begin{array}{l}\text { Does computer help in your typing } \\
\text { skills? }\end{array}$ & 45 & 75 & 15 & 25 \\
\hline Iii & $\begin{array}{l}\text { Does computer help you in your learning } \\
\text { program? }\end{array}$ & 32 & 53.3 & 28 & 46.7 \\
\hline Iv & $\begin{array}{l}\text { Can you store what you were taught in } \\
\text { the class into the computer }\end{array}$ & 53 & 88.3 & 7 & 11.7 \\
\hline V & $\begin{array}{l}\text { Can you use computer to send message } \\
\text { through E-mail? }\end{array}$ & 10 & 16.7 & 50 & 18.3 \\
\hline
\end{tabular}

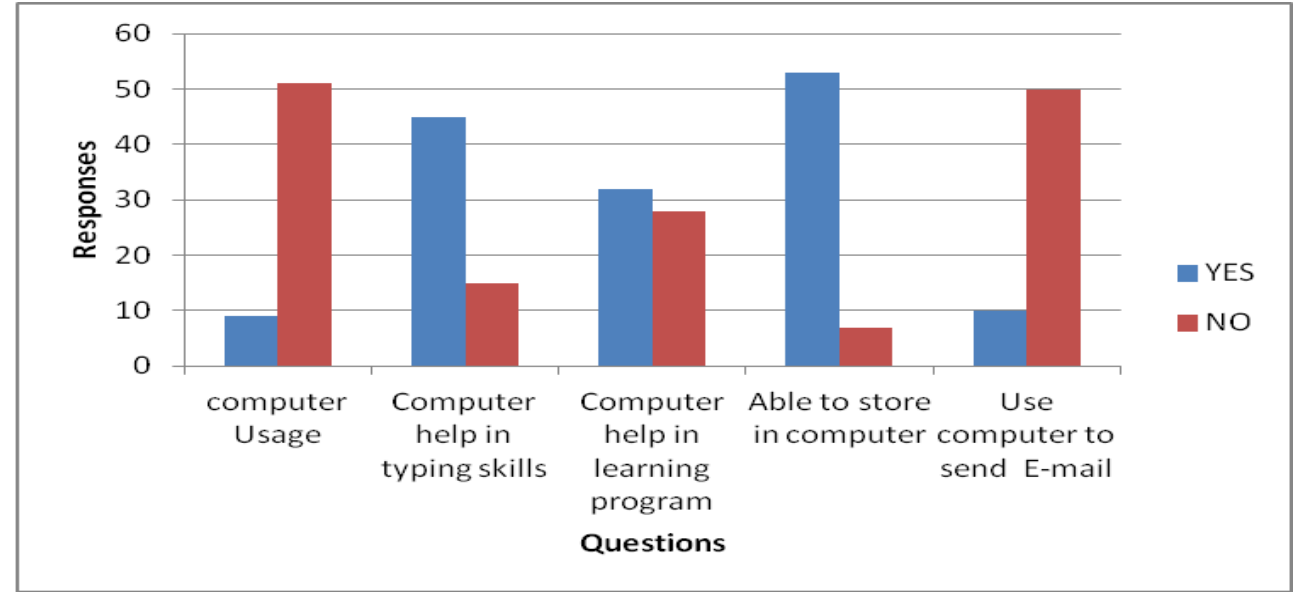

Fig 1: Student response to questions relating to computer usage

Figure 1 vividly shows that only few students have access to computer usage and could use computer to send mails. Majority of them belief, computer helps in typing skills and learning programs while many of them can use computer to store information. 
International Journal of Computer Science, Engineering and Applications (IJCSEA) Vol.6, No.1, February 2016

Table 2: Analysis of Teachers Responses

\begin{tabular}{|c|l|c|c|c|c|}
\hline S/N & \multicolumn{1}{|c|}{ ITEM } & YES & \% & NO & $\%$ \\
\hline I & Do you use computer in teaching? & 12 & 20 & 48 & 80 \\
\hline Ii & $\begin{array}{l}\text { Does your students understand your } \\
\text { teaching well when you use computer in } \\
\text { teaching-learning process }\end{array}$ & 12 & 20 & 45 & 80 \\
\hline Iii & $\begin{array}{l}\text { Do you use computer to solve tutorial } \\
\text { questions for the students }\end{array}$ & 9 & 15 & 51 & 85 \\
\hline Iv & $\begin{array}{l}\text { Are you a trained or qualified computer } \\
\text { operator? }\end{array}$ & 10 & 16.7 & 50 & 83.3 \\
\hline v & $\begin{array}{l}\text { Does computer help you in storage of } \\
\text { information or keeping records }\end{array}$ & 14 & 23.3 & 46 & 76.7 \\
\hline
\end{tabular}

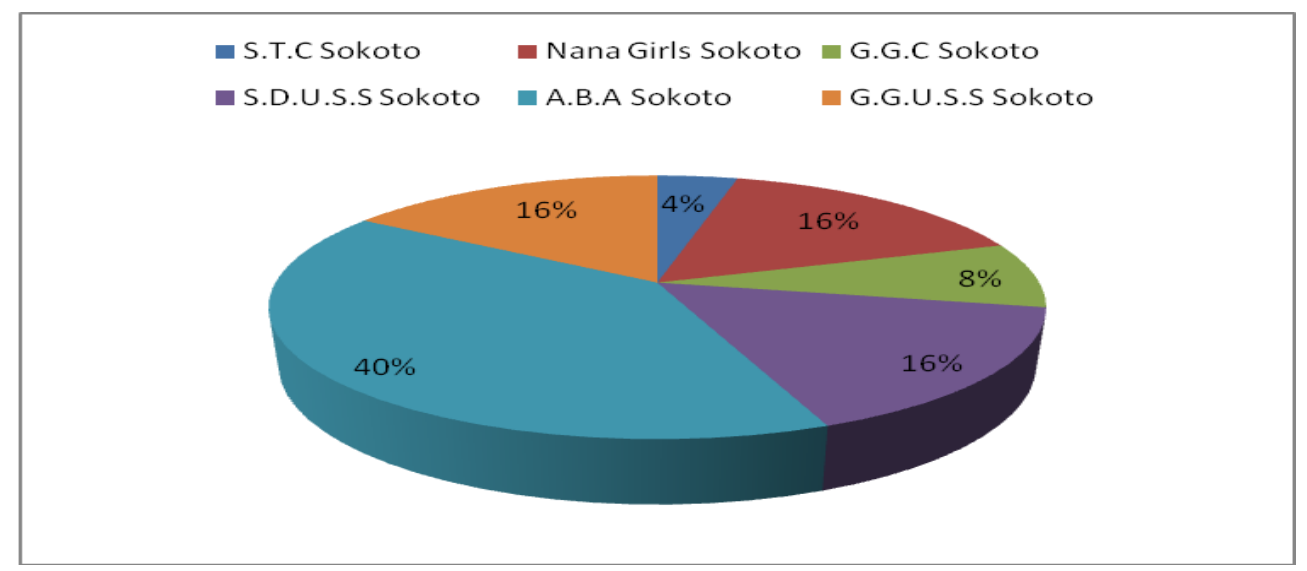

Fig. 2: Percentage of computers in schools

Figure 2 depicts that $\mathrm{ABA}$ has the highest percentage (40\%) followed by three (3) schools SDUSS, Nana Girls and GGUSS with $16 \%$ each, then followed by GGC with $8 \%$ and lastly followed by STC, Sokoto with $4 \%$. 
International Journal of Computer Science, Engineering and Applications (IJCSEA) Vol.6, No.1, February 2016

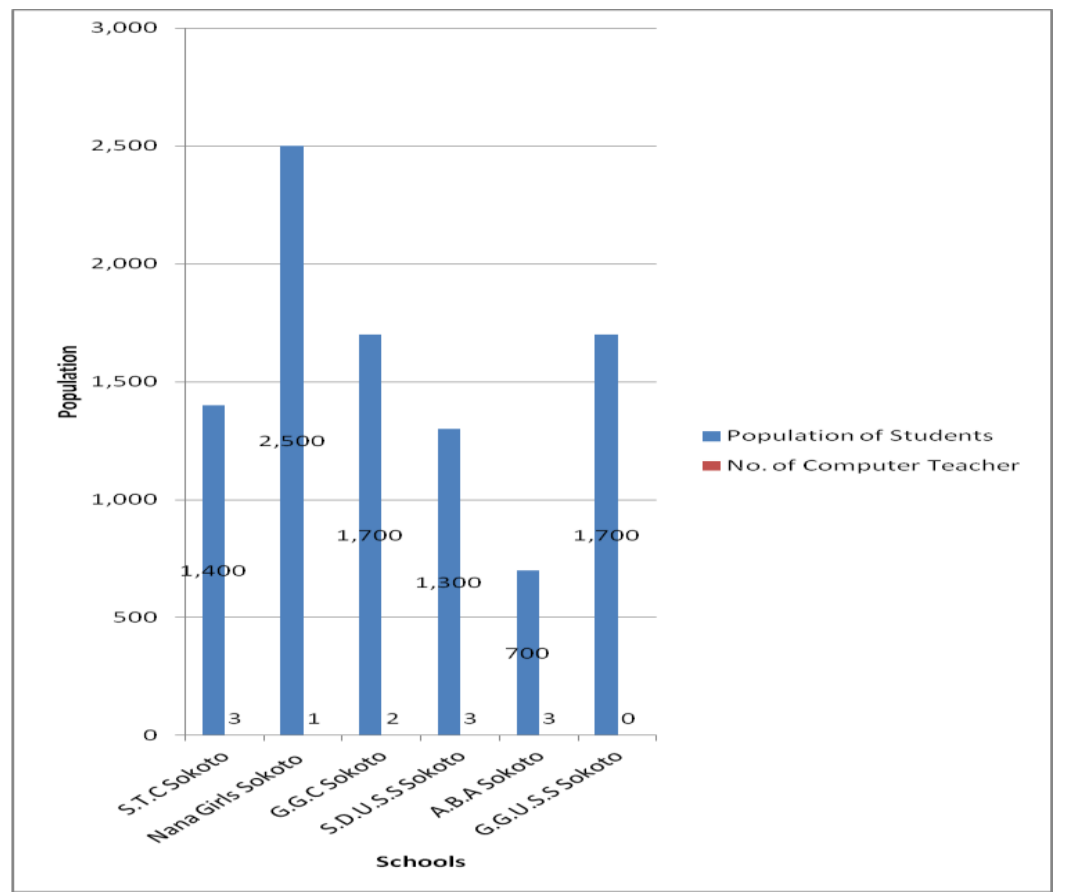

Fig. 3: Comparison of student population with computer science teachers

Figure 3 shows that student population outweigh that of teacher in general.

Table 3: Schools, Number of Computer(s), Computer-Teacher Ratio and Computer-Student Population

\begin{tabular}{|c|l|l|c|c|l|}
\hline S/No & Name of School & $\begin{array}{l}\text { Population } \\
\text { of Students }\end{array}$ & $\begin{array}{l}\text { No. of } \\
\text { Computer }\end{array}$ & $\begin{array}{l}\text { No. of Computer } \\
\text { Teacher }\end{array}$ & $\begin{array}{l}\text { Ratio of } \\
\text { Computer } \\
\text { to Student }\end{array}$ \\
\hline I & S.T.C Sokoto & 1,400 & 01 & 3 & $1: 1400$ \\
\hline Ii & Nana Girls Sokoto & 2,500 & 4 & 1 & $1: 625$ \\
\hline Iii & G.G.C Sokoto & 1,700 & 2 & 2 & $1: 850$ \\
\hline Iv & S.D.U.S.S Sokoto & 1,300 & 4 & 3 & $1: 325$ \\
\hline V & A.B.A Sokoto & 700 & 10 & 3 & $1: 70$ \\
\hline Vi & G.G.U.S.S Sokoto & 1,700 & 4 & 0 & $1: 425$ \\
\hline
\end{tabular}


In all these schools, only Ahmadu Bello Academy being a commercial school has a sizeable population per computer. Due to the population of student and the few numbers of computer in other schools, only some selected class were offering computer. In G.G.U.S.S Bodinga no computer teacher therefore no students is offering computer at all.

\section{DISCUSSION}

The assistance which computer systems provided or offer to educational development can not be over emphasized. It comes to a stage where every school which employs the use of computer testifies to its valued assistance especially in achieving greater results or outputs.

Computers were in use in some of these selected secondary schools in this research work. In all the selected schools, only Ahmadu Bello Academy Farufaru, Sokoto; is a commercial school and has the lowest population of about 700 students. The school was provided with 10 computer machines to aid the study of commercial subjects such as typing. There were only 3 computer teachers and the ratio 1:70 this ratio is remarkable compare to other schools. In other schools, the number of computer ranged from one to four. In Nana Girls and G.G.U.S.S. Bodinga, their accommodation has been provided, next is the installation and staffing, in GGC Sokoto, the students were attending computer classes with one computer and three (3) computer teachers.

The use of computer in learning has helped the students in their leaning programs. In this study $53.3 \%$ of the students' population claimed that learning through computer has enhanced their learning-this agreed with the findings of [4]; and [5]. These authors stressed that computer education had positively influenced students' motivation to learning. About $88.3 \%$ of the students' population can use computer to store information and what they were taught in the class.

Most of the students that were using typewriter machine in typing and those that were not in typing before the introduction of computer into the schools found typing easier on computer, and has improved the typing skills of $75 \%$ of the studied student population. They said they can type with ease and faster when using computer. Typing using computer could enhance or improve educational development [6]. Only $16.7 \%$ of the students' population can use computer to send Email while $83.3 \%$ could use computer to send E-mail. This can be partially explained by the fact that some of the teachers were not teaching the students on how to send Email and again the computer in the schools were not connected to the internet. They need to learn some basic operations.

There were 12 computer teachers in the six selected schools. In teaching-learning processes $85.7 \%$ of the computer teachers claimed that computers helped their student to understand better since the students can revisit the computer for more practice. All computer teachers use computer to store information or keeping records and they also use computer to convert and transmit information suitably. Though the research finding shown not all the computer teacher studied computer either at N.C.E, Polytechnic or University level about 10 teachers or $71.4 \%$ of the computer were qualified while $28.6 \%$ were not trained. 
International Journal of Computer Science, Engineering and Applications (IJCSEA) Vol.6, No.1, February 2016

\section{CONCLUSION}

The research findings showed that computer in secondary schools has helped the students in their typing skills, learning program and helped them to keep useful information in the system while some of the students can also use the computer to communicate or send E-mail easily.

Computer has also helped the teachers in teaching-learning processes, store information or record keeping and also helps them to solve problems and tutorial questions in the class with their students.

Finally, it can be concluded that computer in secondary schools in Sokoto metropolis has enhanced and facilitated the standard of educational development. But the computers and teachers are not enough to be able to make serious impact for students to be able to use them for examinations such as WAEC and JABM.

\section{RECOMMENDATIONS}

Computer usage is viable, possible, feasible and practicable if some things can be put in place as early as possible. Despite its merit, many things are still lacking for it to be appropriately used by examination bodies; hence the following recommendations:

Government should enforce computer training as a core subject and be included in the National Policy on Education.

Government, with the help of private organizations, should provide enough computers to schools.

Computer teachers of high qualification such as NCE, HND with PGDE or Degree holders with educational background should be employed to teach computer.

All schools should have computer laboratory along with multimedia projectors for better learning environment and processes.

Finally, the schools may be given free hand to use the systems to generate funds through business center within the school premises which could serve as encouragement on other subject offered such as entrepreneurship in schools and be of help later in their life and in the maintenance of the systems and laboratory in general. 
International Journal of Computer Science, Engineering and Applications (IJCSEA) Vol.6, No.1, February 2016

\section{REFERENCES}

[1] Sharps (1997), Technology Horizon in Educational Journal. First Edition, Ogfat Publications, UyoNigeria.

[2] Alimi Fatimah $\mathrm{O}$ (2013): Assessment of Availability and Utilization of Science Laboratories in Secondary Schools in Sokoto State, Nigeria. Unpublished Dissertation, Usmanu Danfodiyo University, Sokoto, Nigeria.

[3] Kangiwa U.I. Muhammad H; Abdullah A.F. and Baba Wachiko (1996). The Condition of Secondary School in Sokoto Metropolis. Unpublished Dissertation, Usmanu Danfodiyo University, Sokoto HTP.

[4] Fishman, B. and Amico L. (1994), Networked Computer tools Studying the Weather in Ohmanin and I. Tomak (Eds), Vancouver Publishing, Canada, p. 207-216.

[5] Songer N.B. and Megan M.J. (2000) Student Motivation and Internet Technology. African First Publishers Limited, Akwa-Ibom, Nigeria.

[6] Adewoyin, J.A. (1991). Introduction to Education Technology. Second Edition, Johns Lad Limited, Lagos. 